\title{
Physicochemical and Sensory Properties of Labneh Fortified with Salvia Officinalis
}

\author{
Eman, E. Habib ${ }^{1}$, Sherif,M. Shamsia ${ }^{1}$, Sameh,A. Awad ${ }^{2}$, and Hamid,M. Ziena ${ }^{1}$
}

\begin{abstract}
Labneh is one of the most popular dairy products in the Middle East and has gained immense popularity due to its higher nutritional value compared to traditional yogurt. Labneh is defined as a concentrated yogurt in which yogurt is concentrated by removing acidic whey from the solid parts. Sage "Salvia officinalis" and olive oil have many health benefits as good source of antioxidant compounds. In this study, sage powder and olive oil were in Labneh for increasing its health benefits. The incorporated results showed that the sage powder has no influence on $\mathbf{p H}$, chemical composition and rheological properties, while olive oil significantly reduced the hardness and viscosity of Labneh. The treatments of Labneh with sage powder and olive oil were highly accepted in flavor by panelists. This study recommended that the adding of sage powder could be a good source of antioxidant compounds to increase the health benefits of labneh.
\end{abstract}

Key words: Labneh, sage, olive oil, rheological properties, sensorial properties

\section{INTRODUCTION}

Condensed/concentrated/cheese yogurt known as Labneh in the Middle East and Europe, is a semisolid fermented dairy product made by straining set yogurt until a level of $23-25 \%$ total solids, of which 8-11\% fat is attained (Tamime and Robinson1999; Ozer and Robinson 1999; Hilali et al., 2011; Sanlidere et al.,2013). Labneh is a popular food in various parts of the world especially in the Middle East, chiefly, Syria, lebanon, Turkey and Balkan regions .Labneh is consumed as a main dish at breakfast due to its significant nutritional and good storage characteristics (Nsabimana et al., 2005 and Abd El-Salam et al., 2011). The nutritional and storage characteristics of labneh led to its increasing economic importance (Benezech and Maingonnat, 1994; Nsabimana et al., 2005). one type is prepared to be consumed within two weeks and usually stored in refrigerator and the other type is stored in vegetable oil at room temperature and can be consumed within two years (Keceli et al., 1999). Olive oil preservation by coating the surface of labneh is known to affect the microbiological quality of labneh cheese (Rao et al., 1987 and Keceli et al., 1999). Labneh is high nutritious food compared to yoghurt. It has 2.5times higher protein content, $50 \%$ more minerals, and a considerably larger number of viable beneficial microorganisms than common yoghurt (Nsabimana et $a l ., 2005)$. The organoleptic quality of labneh can be enhanced by addition of herbs.

Sage is a well-known vegetal specie ( $\mathrm{Lu} \&$ Foo, 2002; Bauer et al., 2012; Ben Taarit et al., 2012; Generalic et al., 2012). Many Salvia sub subspecies are used as herbal tea and for food flavoring (Hedge, 1992; Tisserand and Balacs, 1995). Sage preserves a variety of foods, including meats and cheeses (Hedge, 1992; Tisserand and Balacs,1995). Sage is largely used as a savory food flavouring either as dried leaves or essential oil (Perry et al., 1999; Tsai \& Yang, 2011).It is also used traditionally in food preparation. (Cuvelier et al., 1994; Hohmann et al., 1999; Lu and Foo, 2001; Wang et al., 1998; Zupko et al., 2001). Sage leaves was one of the favourite candidate species as a source of natural antioxidants in health care products. (Cuppett and Hall, 1998; Teissedre and Waterhouse, 2000). Rosmarinic acid is the major phenolic compound of sage, also found in many other plants used as seasoning (Petersen \& Simmonds 2003). Earlier studies also demonstrated the presence of carnosol, ursolic acid, oleanolic acid and rosmarinic acid in the leaves of $S$. officinalis (Topçu,2006). Sage has one of the longest histories of use as a medicinal herb. It has a potential in treating cancer as it shows strong antitumor genic activities, as well as in the cosmetics, perfumery and pharmaceutical industries (Hedge, 1992 and Wang et al., 2000). It presents many pharmacological properties, most of them associated with its polyphenol content (Hedge, 1992;Lu \& Foo, 2002; Bauer et al., 2012; Ben Taarit et al., 2012; Generalic et al., 2012).

Considering the previous aspects, the objective of this investigation is to enhance the nutritional value of labneh as functional food by the addition of the leaves of sage in labneh produced from cow milk retentate.

\section{MATERIALS AND METHODS}

Cow milk was concentrated by Ultra filtration (module type of Tubular UF unit, Model 2S 37 (with surface area $2 \times 0.48 \mathrm{~m}^{2}$. The unit was operated under

${ }^{1}$ Department of Food and Dairy Science \& Technology,

Faculty of Agriculture, Damanhour University, Egypt.

${ }^{2}$ Department of Dairy Science \& Technology,

Faculty of Agriculture (El-Shatby), Alexandria University, Egypt

Received October 16,2017, Accepted November16, 2017 
inlet pressure of 5-6 bar and outlet pressure of 2-3 bar at $50 \pm 2^{\circ} \mathrm{C}$. The standardized Cow's milk and retentate were immediately pasteurized at $63^{\circ} \mathrm{C}$ for $30 \mathrm{~min}$ and cooled to $4^{\circ} \mathrm{C}$ and used in the preparation of labneh) at Nasser Secondary School of Agriculture, Damanhour, Beheira Governorate, Egypt. The obtained retentate has $6.4 \%$ fat $-24.39 \%$ total solids, Salvia officinalis (Sage) plant was obtained from local market, Shoubrikhit, Beheira Governorate, Egypt. Lactic acid bacteria commercial lactic culture (DVS Express 0.1, CHR. Hansen, Denmark).LACTA534 stabilizer (Modified starch (E1422) - Gelatin (E441) and mono and diglycerides (E471) was obtained from Misr Food additives, Badr city, Egypt. Permeate concentrate (Fat $1.5 \%$, max -moisture 4\%, max -protein 3\% max) (Holland) .Olive oil was obtained from local market Damanhour Beheira Governorate, Egypt. Plastics cups (100gm) were used in packaging the produced Labneh.

\section{Preparation of Salvia officinalis(Sage):}

The chemical analysis of sage is shown in table (2). Washing the plant and air dried and then the plant is fully grind and added directly to the labneh milk retentate.

\section{Preparation of Labneh}

Cow milk retentate $(6.4 \%$ fat $-24.39 \%$ total solids) was heated to $50{ }^{\circ} \mathrm{C}$ and then $1 \%$ LACTA ( 534) stabilizer and $1 \%$ whey Permeate concentrate were added and dissolved then heated to $80^{\circ} \mathrm{C}$ and kept for 5 minutes. The heat treated mixture was cooled to $45^{\circ} \mathrm{C}$, different levels (0.0 (control), 0.3, 0.5, and $0.7 \%$ herb sage (powder)) of sterilized sage herb (Autoclaved at $121^{\circ} \mathrm{C}$ for 15 minutes) were added (Table 1). The recommended dosage of Starter culture (DVS Express 1) was added, mixed well and then the mixture was incubated at $42^{\circ} \mathrm{C}$ until coagulation. Olive oil was added $1 \%$ of samples (Table 1), all samples were stored at $5{ }^{\circ} \mathrm{C}$ for 20 day.

\section{Chemical analysis:}

Moisture, ash, fat, protein content were determined by the methods of (Ling 1963). The $\mathrm{pH}$ was determined using a digital $\mathrm{pH}$ meter (Mettler Toledo 320, Switzerland) at room temperature $\left(20 \pm 1{ }^{0} \mathrm{C}\right)$ while the titratable acidity was determined according to AOAC, (2007).

\section{Chemical composition of Salvia officinalis(Sage):}

Moisture, protein, fat and ash content were determined in Salvia officinalis (Sage) by official methods of AOAC, (2007).

\section{Microbiological tests of labneh}

OGYA (Oxytetracycline-Glucose-Yeast (Extract) Agar) media was used for yeasts and molds count (Mislivecet al., 1992). Violet red bile agar (VRBA) media was used for Coliform bacterial count (Hitchinset al., 1995).

\section{Sensory Evaluation}

Sensory test was carried out at Department of Food and Dairy Science and Technology, Faculty of Agriculture, Damanhour University. Ten of well-trained panelists were involved. Labneh that were stored overnight at $4 ? \mathrm{C}$ were introduced to panelists in $100 \mathrm{ml}$ yogurt plastic cups. Panelists were individually supplied with plain crackers and directed to have a bite between samples followed by a sip of water to rinse their palate between each sample. More samples were given upon request. Panelists scored their responses onto a print-out paper sheet with a scale of 10 points for texture ,10 points for color,20 points for flavor, and 40 points for overall acceptability (Pearce and Heap, 1974).

Table 1. Ingredients Incorporated in Labneh

\begin{tabular}{ccccc}
\hline Treatments & Olive oil & Sage herb & $\begin{array}{c}\text { Permeate } \\
\text { powder \% }\end{array}$ & $\begin{array}{c}\text { LACTA (534) } \\
\text { stabilizer \% }\end{array}$ \\
\hline C1(control) & - & Zero & 1 & 1 \\
T1 & - & $0.3 \%$ & 1 & 1 \\
T2 & - & $0.5 \%$ & 1 & 1 \\
T3 & - & $0.7 \%$ & 1 & 1 \\
C2(control) & $1 \%$ & Zero & 1 & 1 \\
T4 & $1 \%$ & $0.3 \%$ & 1 & 1 \\
T5 & $1 \%$ & $0.5 \%$ & 1 & 1 \\
T6 & $1 \%$ & $0.7 \%$ & 1 & \\
\hline Table 2. Chemical analysis of Salvia officinalis (sage) & & Sample (sage) \\
\hline \multicolumn{5}{c}{ Properties } \\
Moisture\% & & $11.286 \%$ & \\
\hline \\
Ash\% \\
Total protein\% \\
Total fat\%
\end{tabular}




\section{Rheological properties:}

\section{Textural analysis:}

Textural properties were measured with a texture analyzer (A. XT plus Texture Analyzer, Stable Micro Systems, UK). The software permits the automatic calculation of sample: Hardness, springiness, adhesiveness, cohesiveness, gumminess and chewiness. These texture profile parameters were obtained and calculated as describe by Bourne (1978).

\section{Determination of viscosity:}

Samples were analyzed in the form of labneh and kept at a temperature of $10{ }^{0} \mathrm{C}$ overnight and the Viscosity was measured using oscillatory viscometer (VR 3000M YR Viscometers, Spain).

\section{Statistical analysis:}

All obtained data were statistically analyzed using SAS software program (2000).

\section{RERSULTS AND DISCUSSION}

\section{Physicochemical properties:}

Table (3) shows the physicochemical properties of labneh prepared by addition of 0.0 (control), 0.3, 0.5, and $0.7 \%$ herb sage (powder). Moisture content of labneh samples were in range of $74.33 \%-76.680 \%$ for treatment $(\mathrm{C} 2)$ and treatment $(\mathrm{T} 3)$ respectively at $1^{\text {st }}$ day of manufacturing and then the moisture decreased to $72.810-73.146 \%$ for treatment $(\mathrm{C} 2)$ and treatment (T3) respectively at the end of storage period (20 days at $\left.5^{\circ} \mathrm{C}\right)$. Statistical analysis showed that there were no significant differences $(p>0.05)$ in moisture content among all fresh treatments or during the storage period. The decreasing of moisture content at the end of storage period is related to natural evaporation (Salem et al. 1997, Al-Assar et al. 2005; Shamsia and El-Ghannam 2012 and Shamsia,2017).

Fat percent of labneh was ranged from $6.33 \%$ to $6.60 \%$ for treatment $(\mathrm{C} 1)$ and treatment (T3) respectively at the $1^{\text {st }}$ day of storage. Fat percent of labneh by adding olive oil was ranged from $9.90 \%$ to $10.50 \%$ for treatment (C1) and treatment (T6) respectively at the $1^{\text {st }}$ day of storage. The obtained results showed that there were no significant differences among all treatments made without addition of olive oil in fat content $(p>0.05)$. While the fat content was increased when the olive oil was added and there were no significant differences in fat content $(\mathrm{p}>$ 0.05).among all treatments made with addition of olive oil.

Protein content of labneh samples was ranged from 8.84 to $9.10 \%$ for treatments (T3) and (C1) respectively at the $1^{\text {st }}$ day of storage. Statistical analysis showed that there were no significant differences $(p>0.05)$ in protein content among all treatments of labneh made without addition of olive oil, while the protein content of labneh with adding olive oil decreased to be in range of $6.83-7.00 \%$ for treatment (T6) and treatment (C2) respectively at the $1^{\text {st }}$ day of storage. There were no significant differences $(p>0.05)$ in protein content among all treatments of labneh made with addition of olive oil.

Acidity was ranged from $1.200 \%$ to $1.260 \%$ for treatment $(\mathrm{C} 1)$ and treatment $(\mathrm{T} 3, \mathrm{~T} 6)$, respectively at $1^{\text {st }}$ day of storage and then decreased to $1.25-1.310 \%$ for treatment $(\mathrm{C} 1, \mathrm{~T} 3)$ and treatment $(\mathrm{T} 6)$ respectively at the end of storage periods. There were no significant differences $(p>0.05)$ in acidity content among all fresh treatments or during storage periods. $\mathrm{pH}$ values were ranged between 4.80 and 4.90 for treatment (T3) and treatment $(\mathrm{C} 2)$, respectively at $1^{\text {st }}$ day of manufacturing, while at the end of storage period, the $\mathrm{pH}$ values were decreased in all samples, reached to $4.75-4.85$ for treatment (T3) and treatment $(\mathrm{C} 2, \mathrm{~T} 4)$, respectively, but there were no significant differences $(\mathrm{p}>0.05)$ among all samples. No effects were noticed in acidity and $\mathrm{pH}$ values after the addition of sage powder comparing with the control (Table3). The acidity of Labneh in this study was lower than that reported by El-Smaragy and Zall (1988), as they reported the acidity in Labneh was 1.63\%. However, Tamime and Robinson (1988); Yamani and Abu-Jaber (1994) reported that the $\mathrm{pH}$ (4.0-5.0), titratable acidity $(2.7 \%)$, chemical composition $(74.57 \%$ moisture, $8.3 \%$ protein, $9.8 \%$ fat, $6.37 \%$ lactose and $1.17 \%$ ash) of labneh.

Ash content of labneh samples was ranged between $0.7376-0.854 \%$ for treatment $(\mathrm{C} 2)$ and treatment (T3), respectively at $1^{\text {st }}$ day of manufacturing and then increased to $1.027-1.340 \%$ for treatment (C2) and treatment (T3), respectively at the end of storage periods. There were no significant differences $(\mathrm{p}>$ 0.05) in ash content among all fresh treatments or during the storage periods.

The results of current study were in agreement with that reported by Tamime et al., (1989a, Tamime, 2007), they stated that the total solids (T.S.) were in range of $23-29$, while fat contents was $8.2 \%$ for labneh made from cow's milk using the traditional method. ElSmaragy and Zall (1988) found that the TS was $23.18 \%$ of labneh made from cow's milk using the ultrafiltration technique (UF).

This study confirmed that the addition of sage in Labneh has no effect on the physico-chemical properties of final product during storage. 


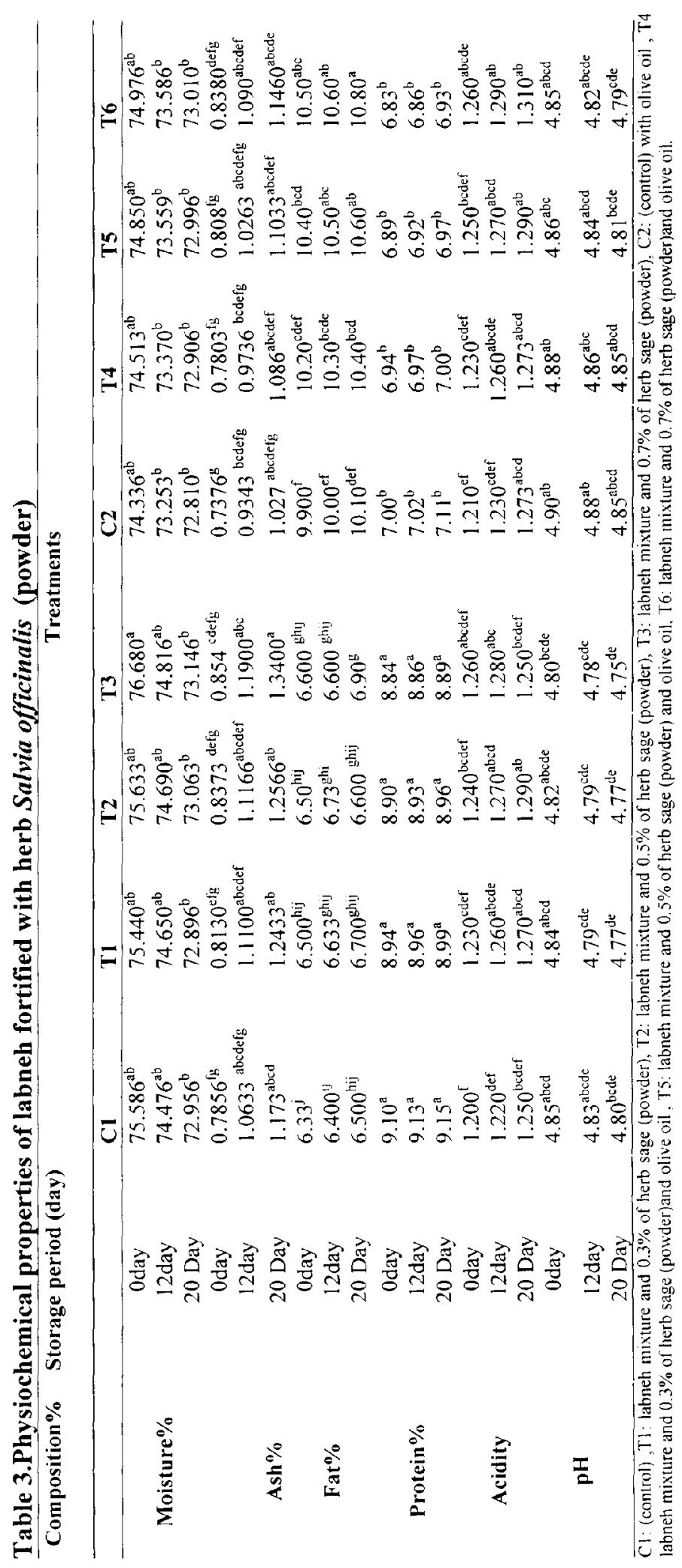


While the addition of olive oil in Labneh has increased the fat content, decreased the protein while it has no effect on the moisture, ash and the acidity and $\mathrm{pH}$ of final product

\section{Microbiological analysis}

The data in Table (4) show that all samples of labneh were free from coliform bacteria, Yeasts and Mold. The results recommended that the addition of herb sage powder could be safe and not a source of microbial contaminations. The microbiological quality meet the Egyptian Standard of fermented dairy products (ES 8042/2016) as it is recommended that the fermented dairy products must be free from coliform bacteria, Yeasts and Mold.

\section{Sensory evaluation:}

Table (5) shows the sensory properties of Labneh fortified with different levels of herb sage (powder). It

Table 4. Effect of treatments on Yeasts\& Molds, total coliform bacterial Count (cfu/g) of labneh fortified with sage salvia officinalis powder

\begin{tabular}{|c|c|c|c|c|c|c|c|c|c|}
\hline \multirow{3}{*}{$\begin{array}{l}\text { Microbial } \\
\text { Test }\end{array}$} & \multirow{3}{*}{$\begin{array}{l}\text { Storage } \\
\text { period } \\
\text { (days) }\end{array}$} & \multicolumn{8}{|c|}{ Treatments } \\
\hline & & C1 & T1 & T2 & T3 & $\mathbf{C 2}$ & T4 & T5 & T6 \\
\hline & & \multicolumn{8}{|c|}{ Count (cfu/gm) } \\
\hline \multirow{3}{*}{ Yeasts\&Moulds } & 0 & N.D & N.D & N.D & N.D & N.D & N.D & N.D & N.D \\
\hline & 12 & N.D & N.D & N.D & N.D & N.D & N.D & N.D & N.D \\
\hline & 20 & N.D & N.D & N.D & N.D & N.D & N.D & N.D & N.D \\
\hline \multirow{3}{*}{ Coliform group } & 0 & N.D & N.D & N.D & N.D & N.D & N.D & N.D & N.D \\
\hline & 12 & N.D & N.D & N.D & N.D & N.D & N.D & N.D & N.D \\
\hline & 20 & N.D & N.D & N.D & N.D & N.D & N.D & N.D & N.D \\
\hline
\end{tabular}

N.D. not detected

C1: (control) ,T1: labneh mixture and $0.3 \%$ of herb sage (powder), T2: labneh mixture and $0.5 \%$ of herb sage (powder), T3: labneh mixture and $0.7 \%$ of herb sage (powder), C2: (control) with olive oil, T4: labneh mixture and $0.3 \%$ of herb sage (powder)and olive oil , T5: labneh mixture and $0.5 \%$ of herb sage (powder)and olive oil, T6: labneh mixture and $0.7 \%$ of herb sage (powder)and olive oil.

Table 5. Effect of addition of Salvia officinalis powder on the sensory evaluation of labneh

\begin{tabular}{|c|c|c|c|c|c|c|c|c|c|}
\hline \multirow[t]{2}{*}{ Properties } & \multirow{2}{*}{$\begin{array}{l}\text { Storage } \\
\text { period } \\
\text { (day) }\end{array}$} & \multicolumn{8}{|c|}{ Treatments } \\
\hline & & C1 & T1 & $\mathbf{T 2}$ & T3 & $\mathrm{C} 2$ & T4 & T5 & T6 \\
\hline \multirow[t]{2}{*}{ Texture(10) } & Oday & $8.500^{\mathrm{a}}$ & $8.333^{\mathrm{a}}$ & $7.916^{\mathrm{ab}}$ & $8.000^{\mathrm{ab}}$ & $8.666^{\mathrm{a}}$ & $8.000^{\mathrm{ab}}$ & $7.500^{\mathrm{abc}}$ & $7.500^{\mathrm{abc}}$ \\
\hline & 20day & $8.0833^{\mathrm{ab}}$ & $8.9166^{\mathrm{a}}$ & $6.7500^{\mathrm{bcd}}$ & $6.2500^{\mathrm{cd}}$ & $8.666^{\mathrm{a}}$ & $8.333^{\mathrm{a}}$ & $6.7500^{\mathrm{bcd}}$ & $6.000^{\mathrm{d}}$ \\
\hline \multirow[t]{2}{*}{ Color(10) } & Oday & $8.666^{\mathrm{b}}$ & $8.0833^{\mathrm{bc}}$ & $7.416^{\mathrm{bcd}}$ & $8.500^{\mathrm{b}}$ & $6.500^{\mathrm{f}}$ & $8.166^{\mathrm{bc}}$ & $7.2500^{\mathrm{bcd}}$ & $7.333 b^{\mathrm{cd}}$ \\
\hline & 20day & $8.666^{\mathrm{b}}$ & $8.750^{\mathrm{b}}$ & $6.666^{\mathrm{cd}}$ & $6.666^{\mathrm{cd}}$ & $6.500^{f}$ & $8.1666^{\mathrm{bc}}$ & $6.500^{\mathrm{cd}}$ & $6.000^{\mathrm{d}}$ \\
\hline \multirow[t]{2}{*}{ (Flavor)(20) } & Oday & $17.500^{\mathrm{b}}$ & $16.416^{\mathrm{bc}}$ & $16.333^{\mathrm{bc}}$ & $14.8333^{\mathrm{cd}}$ & $16.750^{\mathrm{a}}$ & $15.833^{\mathrm{bc}}$ & $14.666^{\mathrm{cd}}$ & $14.250^{\mathrm{cd}}$ \\
\hline & 20day & $15.916^{\mathrm{bc}}$ & $16.333^{\mathrm{bc}}$ & $14.083^{\mathrm{cd}}$ & $12.916^{\mathrm{de}}$ & $16.66^{\mathrm{a}}$ & $16.333^{\mathrm{bc}}$ & $12.916^{\mathrm{de}}$ & $10.833^{\mathrm{e}}$ \\
\hline overall & 0day & $34.833^{\mathrm{a}}$ & $32.83^{\mathrm{ab}}$ & $31.66^{\mathrm{abc}}$ & $31.333^{\mathrm{abc}}$ & $33.66^{\mathrm{a}}$ & $32.000^{\mathrm{ab}}$ & $29.416^{\mathrm{bcd}}$ & $29.083^{\mathrm{bcd}}$ \\
\hline acceptability & 20day & $33.250^{\mathrm{ab}}$ & $34.00^{\mathrm{a}}$ & $27.500^{\mathrm{cd}}$ & $25.833^{\mathrm{de}}$ & $33.33^{\mathrm{a}}$ & $32.833^{\mathrm{ab}}$ & $26.166^{\mathrm{de}}$ & $22.833^{\mathrm{e}}$ \\
\hline
\end{tabular}

$\overline{\mathrm{C} 1}$ : (control) ,T1: labneh mixture and $0.3 \%$ of herb sage (powder), $\overline{\mathrm{T} 2}$ : labneh mixture and $0.5 \%$ of herb sage (powder), T3: labneh mixture and $0.7 \%$ of herb sage (powder), C2: (control)with olive oil, T4: labneh mixture and $0.3 \%$ of herb sage (powder)and olive oil , T5: labneh mixture and $0.5 \%$ of herb sage (powder) and olive oil, T6: labneh mixture and $0.7 \%$ of herb sage (powder)and olive oil. 


\section{Rheological properties of labneh samples:}

Rheological properties of fresh and stored Labneh samples are shown in Table (6).Hardness (the force required to compress a sample between the molars (Awad, 2011)). was widely varied among treatments while the control had intermediate value. Treatment 1 (T1) recorded the highest hardness at the first day of manufacturing, while reduction in hardness was measured in all treatments at the end of the storage period. Hardness was lower in all treatments that contain olive oil when compared with the treatments without addition of olive oil, and the hardness was decreased during storage in all treatments. The reduction of hardness during storage may be due to penetration of oil into the product (Ahmed et al, 2013) and increasing the protein hydration, which rapidly transforms into a smoother and soft product (Awad, 2011).

Adhesiveness (the tendency of labneh material to adhere with other material or surface (Shamsia and ElGhannam,2012)). Data in Table (6) show that the (C2) had the highest adhesiveness value , (T1) had relatively low adhesiveness value at $1^{\text {st }}$ day of manufacturing. While at the end of the storage period, (C1) had the highest adhesiveness value and (T1) had relatively lowest adhesiveness value.

Springiness ( the rate at which a deformed material returns to its original shape on removal of the deforming force (Szczesniak et al., 1963; Bourne, 1978)). Data in Table (6) show that the (T5) had the

Table 6. Effect of addition of herb Salvia officinalis and olive oil on Rheological properties of fresh and stored labneh

\begin{tabular}{|c|c|c|c|c|c|c|c|c|c|}
\hline \multirow{2}{*}{$\begin{array}{l}\text { Textural } \\
\text { properties }\end{array}$} & \multirow{2}{*}{$\begin{array}{l}\text { Storage } \\
\text { period (day }\end{array}$} & \multicolumn{8}{|c|}{ Treatments } \\
\hline & & C1 & T1 & $\mathbf{T 2}$ & T3 & C2 & $\mathbf{T 4}$ & T5 & T6 \\
\hline \multirow[t]{2}{*}{ Hardness(g) } & Oday & 1136.27 & 1272.155 & 1121.529 & 1176.76 & 1085.10 & 869.285 & 1006.61 & 1111.61 \\
\hline & 12 day & 1050.45 & 841.111 & 840.705 & 1126.60 & 880.14 & 986.33 & 686.45 & 1059.41 \\
\hline \multirow{2}{*}{$\begin{array}{l}\text { Adhesivness } \\
\text { (g.sec) }\end{array}$} & Oday & -1030.9 & -229.106 & -646.890 & -570.085 & -1164.04 & -534.99 & -373.80 & -392.97 \\
\hline & 12 day & -1113.4 & -297.513 & -627.18 & -582.24 & -982.28 & -465.4 & -436.2 & -357.74 \\
\hline \multirow{4}{*}{$\begin{array}{l}\text { Springness } \\
(\mathrm{mm}) \\
\text { Cohesivness }\end{array}$} & Oday & 0.928 & 0.988 & 0.960 & 0.978 & 0.955 & 0.980 & 0.990 & 0.960 \\
\hline & 12 day & 0.933 & 0.978 & 0.933 & 0.968 & 0.931 & 0.976 & 0.978 & 0.983 \\
\hline & Oday & 0.533 & 0.394 & 0.522 & 0.489 & 0.554 & 0.506 & 0.508 & 0.488 \\
\hline & 12 day & 0.561 & 0.591 & 0.550 & 0.529 & 0.549 & 0.512 & 0.537 & 0.472 \\
\hline \multirow{2}{*}{$\begin{array}{l}\text { Gumminess } \\
\text { (N) }\end{array}$} & Oday & 606.143 & 501.176 & 584.907 & 575.45 & 601.280 & 439.442 & 511.44 & 542.39 \\
\hline & 12 day & 588.919 & 497.25 & 462.74 & 595.60 & 483.63 & 495.28 & 368.51 & 500.55 \\
\hline \multirow{4}{*}{$\begin{array}{l}\text { Chewiness } \\
\text { (j) } \\
\text { Resilience }\end{array}$} & Oday & 562.633 & 494.973 & 561.743 & 562.640 & 574.490 & 430.74 & 506.381 & 520.91 \\
\hline & 12 day & 549.561 & 486.180 & 431.82 & 562.63 & 450.11 & 498.19 & 361.24 & 491.87 \\
\hline & Oday & 0.166 & 0.177 & 0.177 & 0.143 & 0.139 & 0.122 & 0.161 & 0.160 \\
\hline & 12 day & 0.161 & 0.213 & 0.173 & 0.146 & 0.139 & 0.14 & 0.122 & 1.142 \\
\hline
\end{tabular}

C1: (control) ,T1: labneh mixture and $0.3 \%$ of herb sage (powder), T2: labneh mixture and $0.5 \%$ of herb sage (powder), T3: labneh mixture and $0.7 \%$ of herb sage (powder), C2: (control)with olive oil, T4: labneh mixture and $0.3 \%$ of herb sage (powder)and olive oil , T5: labneh mixture and $0.5 \%$ of herb sage (powder)and olive oil, T6: labneh mixture and $0.7 \%$ of herb sage (powder)and olive oil. highest Springiness value, while $(\mathrm{C} 1)$ had relatively lowest Springiness value at $1^{\text {st }}$ day of manufacturing. At the end of the storage period, the highest Springiness value was found in T6, while (C2) had relatively low Springiness value. Cohesiveness (the strength of internal bonds making up the body of the product (Szczesniak et al., 1963; Bourne, 1978)). Data in Table (6) show that the (T3) had the highest Cohesiveness value, while (T1) had relatively low Cohesiveness value at $1^{\text {st }}$ day of manufacturing. While at the end of the storage period, it was found that (T1) had the highest Cohesiveness value, and (T6) had relatively low Cohesiveness value. The data represented in Table (6) show that the $(\mathrm{C} 1)$ had the highest Gumminess value, while $(\mathrm{C} 2)$ had relatively low Gumminess value at $1^{\text {st }}$ day of manufacturing, but at the end of storage period, (T3) recorded the highest Gumminess value, and (T5) recorded the low Gumminess value. The data of Resilience in Table (6) show that the $(\mathrm{T} 1, \mathrm{~T} 2)$ had the highest Resilience value, and (T4) had relatively low Resilience value at $1^{\text {st }}$ day of manufacturing, but at the end of the storage period (T6) had the highest Resilience value, and (T5) had relatively low Resilience value.

The texture parameters were varied among all Labneh treatments and there were no clear linkages between additions of the sage herb and the texture properties, but the addition of olive oil markedly reduced the hardness of Labneh. There was a decreasing in all hardness values during storage period. 
Table 7. Viscosity (mPa.s) of labneh produced by addition of herb Salvia officinalis

\begin{tabular}{ccc}
\hline Treatments & \multicolumn{2}{c}{ Storage period (day) } \\
\cline { 2 - 3 } & 0 day & 12 day \\
\hline C1 & 84285.25 & 76327.51 \\
T1 & 81136.962 & 74750.66 \\
T2 & 71471.33 & 65887.7 \\
T3 & 76919.70 & 75159.2 \\
C2 & 75493.74 & 62797.66 \\
T4 & 68721 & 59153.05 \\
T5 & 62142.92 & 51064.14 \\
T6 & 73733.25 & 64402.11 \\
\hline
\end{tabular}

C1: (control) ,T1: labneh mixture and $0.3 \%$ of herb sage (powder), T2: labneh mixture and 0.5\% of herb sage (powder), T3: labneh mixture and $0.7 \%$ of herb sage (powder), C2: (control)with olive oil, T4: labneh mixture and $0.3 \%$ of herb sage (powder) and olive oil , T5: labneh mixture and $0.5 \%$ of herb sage (powder)and olive oil, T6: labneh mixture and $0.7 \%$ of herb sage (powder) and olive oil.

\section{Viscosity of labneh:}

Table (7) shows the viscosity values of labneh, the values were ranged between 68721 to $84285 \mathrm{mPa}$.sat/ 10 ${ }^{\circ} \mathrm{C}$ at $1^{\text {st }}$ day of manufacturing, and then the values decreased to the range of $51064.14-76327.51 \mathrm{mPa}$.sat / $10{ }^{\circ} \mathrm{C}$ at the end of storage periods.

comparing with hardness, the viscosity values also decreases at the end of storage period and the treatments with added olive oil also recorded low viscosity values when compared to treatment without olive oil.

The results of present study are in accordance with (Gassem and Frank, 1991;Aryana et al., 2006), they reported a decrease in viscosity of yogurt with increase of storage time.

\section{CONCLUSIONS}

Modern food science and nutrition have suggested the involvement of the ingredients that have antioxidant activities in order to increase the nutritional value of some food products. Since the sage "Salvia officinalis" is used for a long time as medicine, the results of this study concluded that the herb increased the antioxidant capacity of Labneh with no affecting on the chemical and physical properties of final products. As well as Labneh made with herb sage was accepted by panelists. There fore, our recommendation is that the herb sage can be used as a good source of antioxidant compounds to increase the health benefits of Labneh.

\section{REFERENCES}

Abd El-Salam, M. H., A. R.Hippen, K. El-Shafie, F. M.Assem, H. Abbas, M. Abd ElAziz,O.Sharaf and M.ElAassar. 2011. Preparation and properties of probiotic concentrated yoghurt (labneh) fortified with conjugated linoleic acid. InternationalJournalofFoodScience \&Technology.46(10):2 103-2110.

Ahmed, S., H.Umar, F. Muhammad, M.A.Murta . 2013. Quality Evaluation of Olive Oil Coated Labneh Cheese
Mixed with Culinary Herbs .Buffalo Bulletin, Vol.32 (Special Issue 2): 1316-1323.

Al-Assar ,M.A., M.M.El-Abd, W.B. El-Sabie, M. Attia. 2005. Characteristics of low cholesterol Rayeb milk during storage. Egypt .J. Appl. Sci . 20: 739-750.

AOAC. 2007 . Association of Official Analytical Chemists. Official Methods of Analysis. 18 ${ }^{\text {th }}$ Ed. Ch. 34: 72-80. Dairy products, subchapter 8: Gaithersburg, Maryland, USA.

Aryana, K.J., H.T. Barnes, T.K. Emmick, P.Mcgrew, B.Moser. 2006. Lutein is stable in strawberry yogurt and does not affect its characteristics. Journal of Food Science.71: 467-472.

Awad, S. 2011. Texture and Microstructure: in Practical Food and Research pp. 361-391 (ed. Rui M. S. Cru), Nova Science publishers, Inc.

Bauer, J., S.Kuehnl, J.M.Rollinger, O. Scherer, H. Northoff, H.Stuppner,

O.Werz,A.Koeberle.2012.Carnosolandcarnosicacidsfrom $S$ alviaofficinalisinhibitmicrosomalprostaglandin $\quad$ E-2 synthase-1. J PharmacolExp Ther.342: 169-176.

Ben Taarit, M., K.Msaada, K.Hosni, B. Marzouk . 2012.Physiological changes, phenolic content and antioxidant activity of Salvia officinalis L. grown under saline conditions. J Sci Food Agric . 92:1614-1619.

Benezech,T. and J.F. Maingonnat. 1994.Character is ation of the rheological properties of yogurt - a review. J.Food Engine. 21: 447-472.Bourne M. 1978. Texture Profile Analysis. Food Technol.32 (7): 62-66, 72

Bourne, M. 1978 .Texture profile Analysis. Food Technology. 32 (7): 62-66, 72.

Cuppett, S.L. and C.A. Hall. 1998. Antioxidant activity of the labiatae . In:Advances in Food and Nutrition Research. 245-271.

Cuvelier, M.E., C. Berset, H.Richard. 1994. Antioxidant constituents in sage (Salvia officinalis). Journal of Agricultural and Food Chemistry 42: 665-669.

EI-Samragy, Y. A. and R. R. Zall. 1988. Organoleptic properties of the yogurt-cheese labneh manufactured using ultrafiltration. Dairy Industries Int. 53-27. 
Gassem ,M.A., J.F. Frank. 1991.Physical properties of yogurt made from milk treated with proteolytic enzymes. Journal of Dairy Science. 74:1503-1511.

Generalic, I., D.Skroza, J.Surjak, S.S.Mozina, I. Ljubenkov, A.Katalinic, V.Simat, V.Katalinic. 2012. Seasonal variations of phenolic compounds and biological properties in sage (Salvia officinalisL.). Chem Biodivers.9: 441-457.

,I.C. 1992. A Global Survey of the Biogeography of Labiatae. In: Harley R.M., Reynolds T. (Eds.). Royal Botanical Gardens, Kew, pp. 7-17.

Hilali ,M., E. El-Mayda, B .Rischkowskya . 2011. Characteristics and utilization of sheep and goat milk in the Middle East. Small Rumin.

Hitchins, A. D., P. Feng, W. D.Watkins, S. R. Rippey and L. A. Chandler . 1995.Escherichia coli and the coliform bacteria ,p. 4.01-4.29. In Bacteriological analytical manual, 8th ed. AOAC International, Gaithersburg, MD.

Hohmann ,J., I.Zupko, D. Redei, M.Csanyi, G. Falkay, I. Mathe, and G. Janicsak . 1999. Protective effects of the aerial parts of Salvia officinalis, Melissa officinalis and Lavandulaangusti folia and their constituents against enzyme-dependent and enzyme-independent lipid peroxidation. Plant a Medica, 65, 576-578.

Keceli ,T., R. Robinson and M. H.Gordon. 1999. The role of olive oil in the preservation of yogurt cheese (Labneh Anbaris). International Journal of Dairy Technology.52:68-72.

Ling, E. R. 1963 .A textbook of dairy chemistry. Vol. II, $3^{\text {rd }}$ Ed., Chapman and Hall, Ltd. London.

Lu ,Y.R., and L.Y. Foo. 2001.Salvianolic acid L, a potent phenolic antioxidant from Salvia officinalis. Tetrahedron Letters. 42:8223-8225.

Lu ,Y.R., and L.Y Foo. 2002.Polyphenolics of Salvia - a review.Phytochemistry. 59: 117-140.

Mislivec, P. B., L. R. Beuchat and M. A. Cousin . 1992. Yeasts and molds, p. 239249.Inanderzant C.V, and plittstoesser D.F.S(ed.), Compendium of methods for the microbiological examination of foods, 3rd ed. American Public Health Association, Washington D.C.

Nsabimana ,C., B. Jiang and R. Kossah. 2005. Manufacturing ,properties and shelf life of labneh: a review. International Journal of Dairy Technology. 58(3): 129-137.

Ozer, A. H. and R. K. Robinson. 1999. The behaviour of starter cultures in concentrated yogurt (Labneh) produced by different techniques. Lebensmittel- Wissenschaft undTechnologie. 32:391-395.

Petersen , M., MS.Simmonds . 2003. Rosmarinic acid. Phytochemistry .62: 121-125.

Perry, N. B., R. E. Anderson and N. J. Brennan. 1999.Essential oils from Dalmatian sage (Salvia officinalisL.):variations among individuals, plant parts, seasons, and sites.J.Agric. Food Chemist. 47(5): 20482054.

Petersen , M., and MS. Simmonds. 2003.Rosmarinic acid. Phytochemistry .62: 121-125.
Pearce, L. E. and H. A. Heap. 1974.Town milk. J New Zealand Milk Board. 22:18.

Rao ,D. R., A .Alhajali and C.B. Chawan.(1987).Nutritional ,sensory and microbio logical qualities of labneh made from goat milk and cow milk. Journal of Food Science. 52:1228-1230.

Salem, O.M., A.J.Hamed, Y.K.M.K.Kebary, A.S. EL Sisi. 1997.Influence of attenuated lactococci on the quality of Kareish cheese madeby direct acidification. Egypt. J. Dairy Sci. 25:253-268.

SanlidereAloglu, H. and Z? ner. 2013. The effect of treating goat's milk with transglutaminase on chemical, structural and sensory properties of Labneh. Small Ruminant Research.109: 31-37.

SAS Statistical analysis Institute. 2000. SAS User's Guide, Version 4.02 . SAS Inst., CARY, N.C.

Shamsia ,S. M. and M. S. El-Ghannam. 2012.Manufacture of Labneh from Cow's Milk Using Ultrafiltration Retentate With or Without Addition of Permeate Concentrate. Journal of Animal Production Advances. 2 (3): 166-173.

Shamsia, S. M. 2017. Production of labneh fortified with Moringaoliefera as a new functional dairy product. Egyptian of Journal dairy science.44(2):89-97

Szczesniak ,A., M.Brandt, H. Freidman. 1963. Development of standard rating scales for mechanical parameters and correlation between the objective and sensory texture measurements. Food Technol. 22:50-54.

Tamime, A. Y. and R. K. Robinson. 1978. Some aspects of the production of a concentrated Yoghurt (labneh) popular in the Middle East. Mill chwissens chaft. 33: 209-212.

Tamime, A. Y. and R. K. Robinson. 1988. Fermented milks and their future trends. Part II. Technological aspects. J Dairy Res. 55: 281.

Tamime, A. Y. and R. K. Robinson. 1999. Yoghurt science andtechnology .pp. 326-333.

Tamime, A. Y. 2007. Structure of fermented milks. In: Structure of Dairy Products $\left(6^{\text {th }}\right.$ ED). A.Y. Tamine, Blackwell Publishing Ltd., Oxford ox42DQ, UK. Chapter 6 pp: 134-164.

Tamime, A. Y., M.Kalab and G. Davies. 1989a. Rheology and microstructure of strained yoghurt (labneh) made from cow's milk by three different methods. Food Microstructure. 8: 125.

Teissedre, P.L., A.L .Waterhouse. 2000. Inhibition of oxidation of human low-density lipoproteins by phenolic substances in different essential oils varieties. Journal of Agricultural and Food Chemistry.48: 3801-3805.

Tisserand, R., and T.Balacs . 1995. Essential Oil Safety. Churchill Livingstone, New York.

Topçu, G. 2006. Bioactive triterpenoids from Salvia species. J Nat Prod. 69:482-7.

Tsai M. L., Lin C. C., Lin, W. C., \& Yang C. H. 2011. Antimicrobial, antioxidant, andanti- inflammatory activities of essential oils from five selected herbs. Bioscience ,Biotechnology and Biochemistry.7510: 1977_1983. 
Yamani,M. I. and M. M. Abu-Jaber. 1994.Yeast flora of labneh produced by in-bag straining of cow milk set yogurt. J Dairy Sci. 77: 3558.

Wang ,H.o. C.T., M.F. Wei. G.J., T.C.Huang, M.T. Huang . 2000. Chemistry and antioxidative factors in rosemary and sage. Bio factors. 13:161-166.

Wang, M. Li. J., M.Rangarajan, Y.Shao, E.J.LaVoie, T.C. Ho.Huang. 1998. Antioxidative phenolic compounds from sage (Salvia officinalis). Journal of Agricultural and Food Chemistry. 46: 4869-4873.

Zupko, I., J. Hohmann, D.Redei, G.Falkay, G.Janicsak, I. Mathe. 2001. Antioxidant activity of leaves of Salvia species in enzymeede pendent and enzyme-independent systems of lipid peroxidation and their phenolic constituents. Plant aMedica .67:366-368.

\section{الملخص العربي}

\section{الخصائص الفيزيوكيميائية والحسية للبنة المدعمة بعشب المريمية (Salvia Officinalis)}

$$
\text { ايمان حبيب، شريف شمسيه، سامح عوض، حامد زينه }
$$

النتائج أن مسحوق عشب المريمية ليس له أي تـأثثر فــي

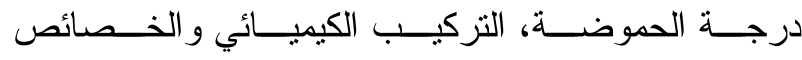

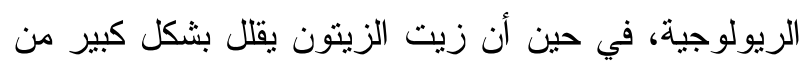

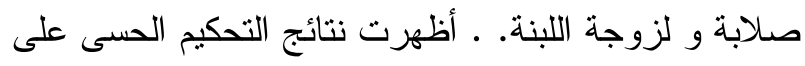

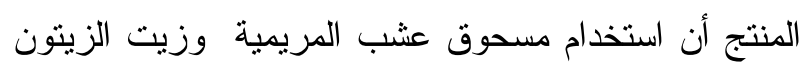

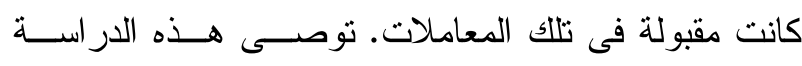

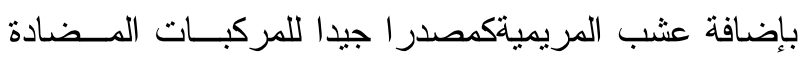

للأكسدة إلى اللبنة مما يؤدى إلى زيادة فو ائدها الصحية.
تعتبر اللبنة واحدة من أكثر المنتجات الألبان شعبية فــي

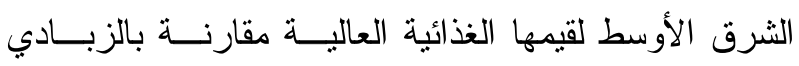

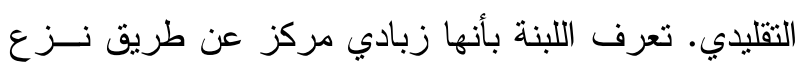

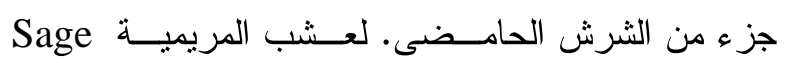

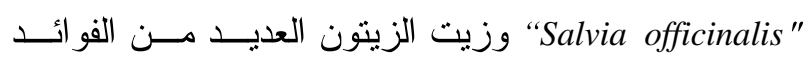

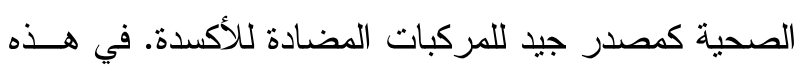

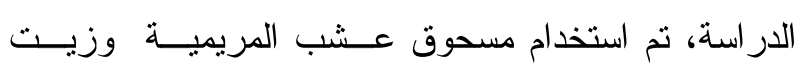

الزيتون في صناعة اللبنة لزيادة فو ائدها الصحية. وأظهرت 